\title{
Solid Biomass Climate Change Interventions Examined in a Context of Inherent Safety, Media Shifting and Emerging Risks
}

\author{
Hedlund, Frank Huess; Astad, John
}

Published in:

Human and Ecological Risk Assessment

Link to article, DOI:

$10.1080 / 10807039.2014 .957954$

Publication date:

2014

Document Version

Early version, also known as pre-print

Link back to DTU Orbit

Citation (APA):

Hedlund, F. H., \& Astad, J. (2014). Solid Biomass Climate Change Interventions Examined in a Context of Inherent Safety, Media Shifting and Emerging Risks. Human and Ecological Risk Assessment, 21(5), 14101427. https://doi.org/10.1080/10807039.2014.957954

\section{General rights}

Copyright and moral rights for the publications made accessible in the public portal are retained by the authors and/or other copyright owners and it is a condition of accessing publications that users recognise and abide by the legal requirements associated with these rights.

- Users may download and print one copy of any publication from the public portal for the purpose of private study or research.

- You may not further distribute the material or use it for any profit-making activity or commercial gain

- You may freely distribute the URL identifying the publication in the public portal 


\section{Solid Biomass Climate Change Interventions Examined in a Context of Inherent Safety, Media Shifting and Emerging Risks}

(Correction appended)

\section{Frank Huess Hedlund ${ }^{1,2}$ and John Astad $^{3}$}

${ }^{1}$ Technical University of Denmark (DTU), Kongens Lyngby, Denmark; ${ }^{2}$ COWI, Kongens Lyngby, Denmark; ${ }^{3}$ Combustible Dust Policy Institute, Santa Fe, TX, USA

Address correspondence to Frank Huess Hedlund, Technical University of Denmark, (DTU) DK2800 Kongens Lyngby, Denmark. E-mail fhuhe@dtu.dk

Running Head: Solid Biomass Climate Change Interventions

\footnotetext{
"This is the authors' preprint version of an article published by Taylor \& Francis Group in Human and Ecological Risk Assessment: An International Journal 21(5):1410-1427 (2015) http://www.tandfonline.com/10.1080/10807039.2014.957954 or http://dx.doi.org/10.1080/10807039.2014.957954
} 


\begin{abstract}
This paper examines recent evidence from Denmark and abroad regarding climate change projects that aim to reduce global carbon dioxide emissions by converting coal-fired thermal power plants to solid biomass fuel. The paper argues that projects appear to be pursued narrowmindedly with insufficient attention paid to safety and points to evidence of media shifting - that the 'resolution' of a problem within the environmental domain creates a new problem in the workplace safety domain. From the perspective of inherent safety the paper argues that the conversion is a step in the wrong direction as a low risk fuel is substituted for a less safe one. Because of rapid scale-up and handling of unprecedented quantities, solid biomass qualify as an emerging risk for which proper control strategies have yet to be developed. The paper finally argues that the tendency to prioritize environmental benefits over safety concerns seems to run deep and not confined to the realm of only solid biomass. Danish environmental ambitions are very high and the costs to society of introducing solid biomass fuels are breathtaking. In this setting, the general failure to address safety risks appears particularly disheartening.
\end{abstract}

Key Words: climate change, sustainable energy, media shifting, inherent safety, wood pellets, dust explosion, smoldering fire, workplace safety. 


\section{INTRODUCTION}

\section{Media Shifting and Inherent Safety}

Environmental interventions may be undertaken with insufficient attention paid to workplace safety (Ashford 1997; Hedlund 2002). Two types of sub-optimalities can be identified: 1) media shifting, which occurs if the 'resolution' of a problem within the environmental domain gives rise to new, and unforeseen, problems within other domains, specifically the workplace safety domain; 2) missed opportunity, which occurs if an opportunity exists for improving both environmental and occupational health and safety performance, but a less optimal solution is chosen that only addresses environmental performance.

The concept of inherent safety, sometimes referred to as primary prevention, relies on preventing the possibility of an accident. By comparison, secondary prevention relies on reducing the probability of an accident. Mitigation seeks to reduce the seriousness of the consequences, i.e., injuries and damage to the environment or property. Inherent safety is seen as a key accident prevention strategy (Ashford 1997; Zwetsloot and Ashford 2003; Ashford 2012; Hedlund et al. 2014).

This paper argues that the unsafe properties of solid biomass have been given insufficient attention in the haste to cut greenhouse gas emissions and examines this climate change intervention in the context of inherent safety and media shifting.

\section{European Climate Change Initiatives}

The EU Energy and Climate Change Package was adopted by the European Council on April 6, 2009. As part of this package the Renewable Energy Directive (OJ 2009) entered into force on June 25, 2009. The Package includes the "20/20/20" goals for 2020:

- A 20\% reduction in greenhouse gas emissions compared to 1990.

- A 20\% improvement in energy efficiency compared to forecasts for 2020 .

- A $20 \%$ share for renewable energy in the EU total energy mix.

The last goal is an overall EU goal. The Directive sets different national targets for member states within this overall goal, based on each member state's capacity. Denmark, for example, will have to reach $30 \%$, while the target for Malta is $10 \%$ (OJ 2009).

The European Commission expects heat and power production from biomass to play an 
important role in meeting the $20 \%$ target for renewable energy use by 2020 and in the future reduction of $\mathrm{CO}_{2}$ emissions in Europe. The EU is currently the world's largest wood pellets market, with a consumption in metric units of approximately 14.3 megatons $(\mathrm{Mt})$ of pellets in 2012 , rising from 4.6 Mt in 2006. The demand is expected to continue to rise to approximately $17 \mathrm{Mt}$ in 2014. Consumption forecasts for 2020 range from $35 \mathrm{Mt}$ for Western Europe to 50-80 Mt for the total EU. Since 2008, the demand for pellets has significantly outpaced domestic production in Europe. This has resulted in increased imports from the United States, Canada, Russia, Ukraine, Belarus, and other countries (FAS 2013).

\section{Danish Climate Change Initiatives}

Denmark's climate policy is very ambitious. In March 2012, Germany announced it would spend 200 billion EUR, corresponding to $8 \%$ of its 2011 GDP, on a plan to shift to renewable energy. This would result in Germany having $80 \%$ of its energy from renewable sources by 2050 (BI 2012a). Shortly after, in Denmark, the minister for climate change, Martin Lidegaard, then announced the "broadest, greenest, and most long-term energy agreement that has ever been reached in Denmark". With the audacious plan, "Denmark will once again be the global leader in the transition to green energy", said the minister (BI 2012b, DEA 2012a). The Danish plan calls for $50 \%$ of the electricity consumption to be supplied by wind power, and to have more than $35 \%$ of final energy consumption supplied from renewable energy sources by 2020 . The longterm goal of the plan is to have a $100 \%$ conversion to renewable energy sources by 2050 (DMCEB 2012).

Due to generous subsidies, windmills already accounted for more than $25 \%$ of Denmark's electricity consumption in 2012. The 2012 energy agreement goes further by the substitution of coal for solid biomass fuel in thermal power plants.

Costs are very large, mainly because the price of solid biomass is double or triple that of coal. Benefits comprise reduced emissions of greenhouse gasses of which the monetary value can be estimated from the European Union Emissions Trading Scheme (EU ETS) prices. Following this line of reasoning, a socioeconomic analysis estimates a benefit/cost ratio of 0.4 , i.e., that benefits amount to only 0.40 cent for each Euro spent on substitution of coal for solid biomass fuel (Johannsen 2011). Many uncertainties influence the estimation, in particular assumptions 
regarding the future supply, demand, and price situation for solid biomass and for EU ETC emission allowances. That uncertainties are large is evidenced by the fact that carbon prices on the European Union Emissions Trading Scheme collapsed in 2013 (Econ 2013). Ignoring benefits, the present value of costs for the anticipated biomass conversion at Danish power plants is estimated at about 24 billion EUR (2011 prices). To provide a sense of scale and magnitude, this amount corresponds to about $10 \%$ of Denmark's 2011 gross national product. Needless to say, this constitutes only a fraction of the total costs of the Danish energy plan, which also comprises subsidies to windmills, biogas, solar energy, etc.

\section{Solid Biomass Fuel in Thermal Power Plants}

Solid biomass refers to non-fossilized carbon-based solid materials derived from plants, such as wood chips, waste wood, straw, milling residues, and certain energy crops grown primarily for the purpose of fuel utilization. Although solid biomass fuel is more expensive than coal it can be made financially feasible, as opposed to economically feasible, by a combination of subsidies and price distorting levies. As a result, Denmark's thermal power generation sector is undergoing a major transformation to be able to handle the new type of fuel.

Thermal power plants consume very large amounts of fuel. For instance, Unit One at Amagerværket near Copenhagen, which entered into dedicated biomass fuel service by mid2010 , consumes about $450,000 \mathrm{t}$ of solid biomass fuel per year. In order for the logistics chain to handle such large quantities, the biomass is processed into pellets, usually about $8 \mathrm{~mm}$ in diameter and 20-25 mm length. In the manufacturing process, the biomass is milled to a powder and then compressed into pellets, using die ring press and compression roller technology. The electricity consumption is significant. Due to compression heat, pellets exiting the die are too hot to touch and they may even carbonize in the die and block the bores. Some of the biomass for Danish power plants is shipped half-way round the globe from plantations in North America or Africa that operate according to sustainable environmental management principles. Because the pellets' energy content per unit volume is anywhere from half to one-third of that of coal, handling and storage facilities at the power plant must double or triple in capacity. Large thermal power plants are dust fired and the pellets will therefore be ground back to dust immediately before being blown into the fluidized bed combustion zone. 


\section{HAZARDS OF SOLID BIOFUELS}

\section{Key Issues}

The hazard profile of biomass pellets is much different from that of coal. Biomass pellets may well qualify as an emerging risk for which proper control strategies have yet to be developed. There are two key issues. The first relates to the mechanical stability (friability) of the pellets and the generation of dust. The second relates to the complex hazard profile of this combustible dust.

\section{Dust Explosion}

When handled, biomass pellets generate fine dust in quantities posing a risk for dust explosions. The coal used in Danish power plants also generates dust during handling, but in smaller quantities and usually coarser, although coal silo dust explosions are a recognized hazard. The storage areas present new emerging risks. Coal is not sensitive to moisture and is usually stored bulk in large outdoor piles. In contrast, biomass pellets do not tolerate moisture, which turns them into a worthless viscous sludge. Pellets must therefore be handled under roof or in silos. The limited ventilation in such enclosures increases the dust explosion probability, and the confinement aggravates the severity of the blast, should an explosion occur. In contrast to coal, the biomass pellet dust explosion risks affect the entire logistics chain. ${ }^{1}$

Dust explosions have traditionally been difficult to deal with in industry. Part of the problem lies with the limited general understanding of the complex mechanism of dust explosions among plant operating personnel as well as corporate management. Dust explosions can either be primary or secondary. A primary dust explosion occurs when a dust suspension within a container, room, or piece of equipment is ignited and explodes. In contrast, a secondary explosion occurs when combustible dust, which has been allowed to settle and accumulate on floors or other horizontal surfaces due to inadequate housekeeping or inadequate local exhaust ventilation, is made airborne by the pressure wave of primary explosion and subsequently ignited

\footnotetext{
${ }^{1}$ Some coals can also affect the entire logistics chain. US Powder River Basin (PRB) coal is more friable, the
} ignition sensitivity is lower and explosive severity is higher than other coal grades. 
by the slower moving subsonic flame front. Depending on the extent of the dust deposits, a weak primary explosion may cause very powerful and catastrophic secondary dust explosions.

Dust explosion hazards can be difficult to recognize because the workplace, when superficially inspected, may falsely appear dust free due to unseen dust deposits in hard to reach overhead areas and where the atmosphere presents as free of dust and safe at face value. Additionally, dust may appear coarse on inspection but the fine dust responsible for the first explosion may accumulate over time in hard to reach locations such as on top of overhead Ibeams, lighting fixtures, etc.

The explosion severity or dust deflagration index $\left(\mathrm{K}_{\mathrm{st}}\right)$ and the maximum pressure $\left(\mathrm{P}_{\max }\right)$ provide single number indicators of the outcome of a dust explosion. The larger the value for $\mathrm{K}_{\mathrm{st}}$ and $\mathrm{P}_{\max }$ the more severe the explosion. Example $\mathrm{K}_{\mathrm{st}}$ values for coal dust, which indicate the rate of pressure rise, may be in the range of 125 whereas wood dust may have $\mathrm{K}_{\text {st }}$ values around 160 (Melin 2008). Although measurements are carried out according to American Society for Testing of Materials (ASTM) or European Committee for Standardization (CEN) standard test conditions, measured values may exhibit considerable variation due to differences in moisture content, particle size distribution and chemical composition. To our knowledge, measurements of dust from biomass pellets have occasionally produced $\mathrm{K}_{\text {st }}$ values in excess of 200 . Huéscar et al. (2013) point to a number of uncertainties in the test procedure and observe that $\mathrm{K}_{\text {st }}$ and $\mathrm{P}_{\max }$ values of biomass powders are often over- or underestimated and flammability limits do not agree in many cases when using standard equipment. They argue that there is a lack of reliable data of biomass explosibility.

Good control of ignition sources is an essential part of any dust explosion risk management strategy and is codified into European ATEX (ATmosphères EXplosibles) legislation. Hedlund et al. (2014) argue that available guidelines for ATEX hazardous area classification for combustible dust are insufficiently developed, in particular when compared with the far more detailed guidelines available for flammable gasses and vapors. The absence of detailed recommended guidelines gives ample room for potentially erroneous subjective individual judgment in hazardous area classifications for combustible dust, ultimately to the effect that the control of potential sources of ignition may be inadequate.

For sake of comparison, "ordinary" industrial dust explosions are known to have 
catastrophic potential, like the sugar dust explosion that ravaged the Imperial Sugar refinery in Georgia, USA, in 2008 and killed 14 people (CSB 2009). Experience has also shown that wood dust certainly has catastrophic potential. A wood dust explosion destroyed the Babine Forest sawmill in British Columbia, Canada, on January 20, 2012, killing two workers and injuring 20 others (WorkSafeBC 2013). A few months later, on April 23, 2012, another wood dust explosion levelled the Lakeland Mills sawmill in British Columbia, Canada. The explosion travelled through the premises and collapsed the main lunchroom walls onto the workers assembled there. Workers in the basement-level lunchroom were blown out a wall by the force of the explosion. Two workers died as a result of their injuries, and 22 others were injured. (WorkSafeBC 2014). The explosion was powerful enough to blow debris 400 meters away from the sawmill and shake buildings and rattle windows several kilometers away (VS 2012).

\section{Ease of Ignition and Smoldering Fires}

Experience has shown that dust from biomass pellets easily ignites. Likely ignition sources are overheated rotating devices (ball bearing, idler, guide roller, etc.) or an electrostatic discharge or mechanical spark, for instance from a piece of iron or a stone transported with the biomass. Biomass pellet piles are also known to self-ignite, particularly if moist. Smoldering fires are difficult to detect and the smoldering particles may migrate in the band conveyor systems. Smoldering fires may develop into massive storage fires and cause considerable damage to process equipment and property. Worse, smoldering fires may act as sources of ignition, when pellets are transported and inevitably generate airborne dust, triggering a primary dust explosion or flash fire presenting serious risk to nearby personnel.

Smoldering fires are notorious for their capacity to generate pyrolysis gasses that travel and accumulate, leading to flash fires or explosion hazards when firefighters attempt to attack the fire. Smoldering fires in silos have an additional hazard in the generation of pyrolysis gases providing a fuel rich atmosphere above the upper explosion limit. This condition can rapidly change when firefighters open silo access covers during firefighting activities introducing oxygen, which then creates an explosive atmosphere resulting in a severe backdraft explosion. 


\section{Carbon Monoxide}

Biomass pellets emit carbon monoxide, which has produced fatal accidents in cargo ships or in storage silos. Fatal accidents have also occurred in wood pellet storerooms of private households even though the compartments were ventilated in accordance with normal building codes (Gauthier et al. 2012).

\section{SOLID BIOMASS FUELS - EVIDENCE OF AN EMERGING RISK}

\section{Data Sources}

Biomass pellets are not classified as a dangerous substance and to our knowledge there is currently no mechanism to register fire and explosion incidents specifically involving biomass pellets. This would particularly be true for fires and explosions that only cause damage to company property. This class of events is highly significant to safety professionals though, as they can be interpreted as precursors to more serious accidents, i.e., that they under marginally different circumstances would have led to a worse outcome, involving human casualty (Phimister et al. 2004).

There are numerous news media reports of fires and explosions involving biomass pellets. Information is often sketchy, as news media are interested in the immediate event and prioritize promptness over accuracy. It takes considerable effort and time to identify causes, indicating heat sources, equipment involved ignition, area of origin, and contributing factors, including organizational issues, and at this stage media interest has usually long waned. We personally know of fires and explosions that did not find way into the media and expect that this occurs frequently.

The combustible dust-related incidents listed below have been selected for the following reasons: 1) they illustrate the inherent hazards of biomass pellets discussed above; 2) they illustrate the vulnerability of the installations and the damage caused by fires and explosions; 3 ) they show the difficulties and complexities that emergency responders face; 4) they show accidents are ubiquitous, no country or region is spared; or 5) for sites where multiple incidents have taken place, because they give an indication of the prevalence, if not normalcy, of such events. 


\section{Incidents}

\section{Major storage fire, Denmark (2012)}

On August 12, 2012, employees noticed smoke from a biomass pellet conveyor belt at 30 $\mathrm{m}$ height at Avedøreværket, a thermal power plant in Denmark, on the outskirts of Copenhagen. The incident is described by Weinreich (2012) but many details are sketchy. Reportedly, the incident took place when pellets were being unloaded from a ship. It was speculated that an overheated roller bearing in the transport conveyor system had ignited the pellets. At the time of discovery of the fire, smoldering pellets had already entered the $45,000 \mathrm{~m}^{3}$ storage silo (the "small storage silo"). The information available indicates that the fire design case involved selfignition of pellets in the silo, for which the silo had an inert gas system. The actual fire was more intense than the design case however, and the inert gas supply quickly became exhausted. There was no fixed sprinkler system in the silo.

Fire hoses were not engaged out of fears for kicking up dust, triggering a dust explosion. The concern was that the concrete silo walls would be unable to withstand the blast, perhaps even endangering the nearby power plant at distance $400 \mathrm{~m}$. Water is also unwanted in the silo, as the pellets were said to expand five-fold, the pressure exerted could lead to a silo collapse, which would cause destruction to extensive subterranean conveyor systems. Daily, $170 \mathrm{t}$ of inert gasses were trucked in to quench the fire, local production capacity was exceeded and supplies came in from southern Sweden. The fire was only extinguished after almost 2 weeks of firefighting, which involved emptying the silo and moving the pellets to large piles outside. Ten days into the incident a smoldering fire was discovered in the "large storage silo" with a pellet capacity of $100,000 \mathrm{~m}^{3}$, said to be one of the largest of its kind in the world. This fire was eventually successfully extinguished. The $45,000 \mathrm{~m}^{3}$ storage silo was a complete loss however, and there was extensive damage to conveyor systems. Although the power plant is located well away from populated areas nearby residents were nevertheless requested to have windows shut because of the considerable smoke generation. There were no injuries as a result of the fires. The Danish fire and rescue services later said it was one of the most complex fires they had faced in recent times (Weinreich 2012). 


\section{Belt conveyor systems ignite pellets, two cases from USA (2012)}

At Avedøreværket, pellets on fire entered the silo from the top via a conveyor belt. There are several similar incidents abroad. According to news reports it happened, for instance, three months prior to the DONG incident in the wood pellet conveyors and storage silo of Port Panama City, Florida, USA, on May 3, 2012 (Osborne 2012), and 2 weeks later, on May 16, in the conveyors/silos of the Port of Savannah, Georgia, USA, also involving wood pellets (SMN 2012).

\section{Dust explosion in silo, Denmark (2012)}

On May 11, 2012, a dust explosion occurred in a biomass pellets silo at Amagerværket, another thermal power plant in Copenhagen, which injured three persons. The case is described by Andersen (2012). The dust explosion hazard had not been recognized and the accident took place when contractors were clearing out a silo blockage using a so-called bang-and-clean method without taking proper precautions. This method is commonly used to clean boiler tubes for slag deposits and involves a controlled explosion of a bag filled with methane and oxygen. The shockwave is intended to dislodge the deposits from the boiler tubes after which they fall to the fire box floor. The accident took place when the controlled explosion ignited biomass dust in the silo. A contractor was injured with burns to $20 \%$ of the body, but the accident appears to have had multiple fatality potential (Andersen 2012).

The same power plant experienced a biomass pellet silo fire Dec 17, 2012. At the time of the fire the silo held 4,000 t of pellets (Bredsdorff 2012). Information is sketchy but it appears the fire was extinguished without incident.

\section{Fire causes extensive power station damage, UK (2012)}

In February 2012, the Tilbury Power Station, UK, was ravaged by a fire in 4,000-6,000 t of wood pellets. The fire started in a hopper containing the wooden pellets and was described by one senior fire officer as among the most challenging he had dealt with in his 20 -year career.

The fire spread to biomass conveyors high up in the power station building. The fuel goes into vats and is taken into the plant on a conveyor belt. There were several concerns. For instance, the fuel cells are designed to carry dry fuel so pouring water on to them and making 
them significantly heavier could potentially damage the structure of the building. Additionally, there was a concern that when the cells get wet, then dried by the fire, a crust will develop, making it impossible for more water to penetrate the fire underneath. More than 120 firefighters from across the county had been dispatched to fight the fire. Opened in 1969, Tilbury previously operated as a coal-fired power station but was converted to generate power from $100 \%$ sustainable biomass (Guardian 2012).

Systems were extensively damaged. The first of the station's three units was returned to service only after more than $3 \frac{1}{2}$ months of repairs. The fire is thought to have developed from a localized smoldering incident. Despite fire suppressant foam had been used to cap the affected areas, significant air drafts led to fire intensification, which damaged hoppers and conveyor systems (PE 2012). There are no reports of injuries.

\section{Dust explosion in bulk storage building, pellet plant, Denmark (2010)}

On September 16, 2010, a dust explosion took place at a biomass pellet manufacturer near the small town of Aars, Denmark. The facility produced biomass pellets for the domestic stoker furnace home heating market and received waste wood chips from furniture manufacturing and a wide range of other waste wood or biomass streams. The pellet manufacturing units were located in a neighbor building and a front wheel loader grabbed milled raw materials from different cell compartments inside a storage building and dropped them into a mixing feeder chute that fed the pellet presses. The front loader made wood dust airborne and ignited the dust resulting in flash fire and a confined explosion. The driver received fatal burn injuries and the entire storage building burned down. The likely source of ignition was the parking brake of the wheel loader, which was not released and quickly overheated. The facility experienced another serious explosion in 2002, which destroyed the same storage building but resulted in no human casualties. Hedlund et al. (2014) argue that the case offers a text book example of the truism that if accidents are not investigated, and root causes not identified, they recur. Had the company chosen to rebuild the facility in 2010 , which this time they did not, a future repeat explosion would be likely. 


\section{Fires and explosions in biomass pellet plant, Canada (2010)}

On December 19, 2010, an explosion blasted the Pacific BioEnergy wood pellet plant in Prince George, British Columbia, Canada. Fires were fought by 17 firefighters from three local fire services and damage was reported as being "major". Two back-to-back explosions rocked this same pellet plant on March 31, 2008, and a fire broke out at the plant in August 2009 (ForestTalk 2010).

\section{Dust explosion in hammer mill section of pellet plant, Germany (2009)}

In Ettenheim, Germany, a pellet producer reported a dust explosion in the hammer mill, which is the pulverization step before compressing the biomass into pellets. This was said to be a "quite normal" occurrence in this kind of facility, they had two such incidents in July alone (BZ 2009).

\section{Explosion at the world's largest pellet plant, Georgia, USA, 2011}

The Waycross facility in Georgia, USA, owned by RWE, is the largest pellet facility in the world with an annual production about 750,000 t. In late June 2011 a dust explosion sparked by an overheated roller-bearing assembly led to a shut-down. Repairs and modifications to the plant were completed in mid-July 2011. The explosion occurred in the early morning resulting in no casualties (RIM 2011). There does not appear to be additional information available on this incident in the public domain.

\section{Explosion at "Inferno Pellets", USA, 2013}

A dust explosion at "Inferno Pellets" in East Providence, Rhode Island, NY, USA, took place Aug 20, 2013. The explosion threw a worker 20 feet initiating a fire covering an area roughly the size of a football field. More than 100 firefighters were called to battle the blaze (Dujardin 2013). At one point, firefighters were pulled out of the building because the fire had spread up into the roof area, making it unsafe for firefighters (Rupp 2013).

Kalunian (2013) later reported that the local Fire Department had been called to Inferno Wood Pellets 42 times in the last 12 months, but that the local fire chief said he "didn't think that was excessive". 


\section{Port of Tyne, UK (2011)}

On Oct 30, 2011, a 100,000 $\mathrm{m}^{3}$ stockpile of wood pellets at the Port of Tyne, UK, caught fire early Sunday morning. Wood pellets received at the port are taken by train to the biomass fueled Drax power station in Yorkshire. The pellets were said to have ignited spontaneously deep inside the pile in a $150 \mathrm{~m}$ by $60 \mathrm{~m}$ concrete storage unit. The port had a fire monitoring system but unfortunately the fire was only detected by the system when a deep seated fire had taken hold. Firefighting efforts were initially delayed because a build-up of carbon monoxide first had to be cleared. Then firefighters began digging into the stockpile with mechanical diggers to uncover the burning wood pellets and extinguish the flames. The process was said to be relatively simple but very time-consuming. The port stated there was no damage to property and minimal impact on port operations (Butcher 2011).

\section{Nature's Flame pellet factory in Rotokawa, New Zealand, 2013}

On September 4, 2013, Nature's Flame in Rotokawa, New Zealand, a business providing sustainable wood pellet heating, suffered a dust explosion and a major fire. There were no reports of injuries. Information is sketchy, but the dust explosion was said to have involved two saw dust hoppers (NZH 2013).

\section{New England pellet mill dust explosion and fires, USA, 2011}

On October 20, 2011, a wood pellet manufacturing facility in New Hampshire, USA, experienced a series of fires and dust explosions. A problem in a pellet mill caused a spark or ember to travel from the mill, along a collection conveyor, up a bucket elevator, then along a second conveyor and into the pellet cooler where wood pellets ignited and caused a combustible dust-related major fire. The fire then travelled through a bucket elevator transport system to a storage silo.

It also spread through the ductwork to a dust collector, which exploded. The duct burst open and released the pressure of the deflagration inside the building near firefighters, who were responding to the fire. The dust collector's door was blown off its hinges, creating a missile hazard. The explosion blew out through an undersized explosion vent onto two storage silos, 
which were ignited.

This accident is both interesting and noteworthy. Interesting, because the broad palette of solid biomass hazards plays out: ignition, fire, travelling embers, explosion, missile and escalation. Noteworthy, because the U.S. Occupational Safety and Health Administration (OSHA) citation offers a rare rich description of consequences and safety deficiencies (OSHA 2012).

The OSHA citations for unsafe fire and explosion conditions were numerous. Following the explosion and fire at the wood pellet mill, OSHA inspectors found excessive layers of combustible dust on numerous horizontal surfaces in the production, dryer, and hammer mill rooms. This hazardous condition is a prelude to a secondary catastrophic explosion if the dust layers become airborne and ignite following a primary dust explosion. The poor housekeeping situation was exacerbated when OSHA inspectors discovered that employees were using compressed air at excessive pressures to clean workplace surfaces. This improper work practice generates dust clouds at explosive concentrations.

These operational deficiencies were only the tip of the iceberg in the hazardous fire and explosion conditions in the wood pellet mill. Beneath the surface were insufficient engineering control measures required in minimizing the severity of consequence when a fire or explosion occurs. For example, best engineering practices require spark detection and fire suppression in addition to isolation of interconnected process equipment so as to prevent the propagation of fires and explosion throughout a facility.

Process equipment lacking such fire and explosion engineering controls included the pellet mill, pellet cooler, silos, dust collectors, and conveyor system. Facility design is another crucial area. For instance, OSHA also cited the facility for the improper location of the hammer mill located indoors exposing workers to combustible dust fire explosion hazards. This type of equipment is allowed indoors only if located in a detached building or separated from other production areas by damage limiting construction as noted in the National Fire Protection Association combustible dust standards.

Best engineering practices in facility design shall also include the location of the rotary dryer outdoors, or in a separate detached building, or in a separate cut-off room protected by damage limiting construction. OSHA cited the facility for this deficiency in addition to the 
failure of the employer to ensure the rotary dryer was inspected and cleaned of built up combustible dust and resin deposits. Managing fuel sources is only one leg of the fire triangle that must be addressed in minimizing the probability of occurrence.

OSHA inspectors also found that management failed to comprehensively manage unique ignition sources. These potential ignition sources include portable industrial vacuum cleaners and powered industrial truck such as fork lifts, wheel loaders, etc.,. that need to be rated for operation in potential explosive atmospheres.

The OSHA citations at this wood pellet facility following the fire and explosions provide excellent examples with lessons-learned, illustrating the importance of information sharing in implementing best engineering and operational practices.

\section{DISCUSSION}

\section{Insufficient Attention Given to the Hazards of Wood Pellets}

In 2010, Gordon Murray, the executive director of the Wood Pellet Association of Canada, gave this blunt and vivid account of the hazards of the wood pellet business:

"The wood pellet business is hazardous. Dock workers have unknowingly entered loaded ship holds and perished from carbon monoxide emitted by wood pellets. Many times, rainwater has leaked into a storage silo, causing the pellets to self-heat and eventually burst into catastrophic fire. Workers trying to extinguish the fire then cut holes in the side of the silo, only to cause explosions, injuries, and deaths. [...] Such incidents happen too frequently, not only in Canada, but in pellet plants around the world. [...] Canadian insurance companies have recently told the pellet industry that its performance must improve or else pellet plants will no longer be insurable. [...] Pellet producers must create an industry-wide culture in which the health and safety of workers is an overriding priority" (Murray 2010).

There is anecdotal evidence of numerous small combustible dust-related fires and occasional dust explosions in Danish biomass pellet operations. But firm empirical data are difficult to obtain. There is little mention of incidents in public sources, there is no central registry, and as long as incidents occur on private property resulting in no-casualties referred to as "near misses" and only cause limited property loss, they appear to cause minimal attention. More succinctly, paraphrasing Vaughan (1996), a process of "normalization of deviance" appears 
to take place.

A pellet facility in Denmark manufactures about 100,000 $\mathrm{t}$ per year of biomass pellets. International experience referred to above indicates that facilities of this kind are known to experience frequent combustible dust-related fires and explosions. Yet, judged from the lack of publicly available information, the facility would appear to have avoided the fires and explosions occurring at similar biomass pellet facilities abroad. A wide search in the comprehensive Infomedia database covering all Danish news media articles since about 1990, produces only a single local news account of a silo fire at the facility.

Inspired by the fire and explosion at "Inferno Pellets" in 2013 referred to above, after which Kalunian (2013) reported that the local Fire Department had been called to the facility 42 times in the last 12 months, we decided to carry out a similar analysis. The Danish fire services keep a central registry (ODIN) of fire station turnouts. All fires at the pellet facility can reasonably be assumed to be related solely to pellet production and handling. The ODIN database was interrogated for turnouts to the facility for the period December 2006 to October 2012. These produced 58 turnouts, of which 23 were blind (alarm from automatic fire-detection system, but no fire) and 6 were false. The remaining 29 were real, corresponding to a real fire every 73 days.

The pellet facility is certified to ISO 14001 and OHSAS 18001 and it publishes a yearly "Grønt regnskab", which translates into a "Green statement". The green statements for 2011 and 2012 comprise various lost time injury (LTI) metrics and identify the most important working environment issues under the following five headings: 1) noise, including bad acoustics; 2) psychosocial issues; 3 ) indoor environment issues, drafts and cold spots, radiant heat and indoor air quality; 4) accident risks, slips, falls, nip points between rotating machine components, fire and explosion, hazards arising from contact with electricity and other energy sources; and 5) nuisance dust. In our opinion, the company gives genuine attention to occupational health and safety. Nevertheless, the green statements do not mention a single fire incident despite that ODIN registrations indicate at least eight real fires for the period. The green statements identify 14 workplace health and safety issues, only the 11th is fire and explosion. We are perplexed at this finding and wonder if green reporting and environmental statements, even if they have sections covering occupational health and safety, adequately capture occupational accident risk. Because only one fire incident found way into news media we suspect that gross underreporting is the 
norm.

Although we cannot say that we have meticulously examined each and every life cycle analysis (LCA) on the use of solid biomass as a sustainable carbon-neutral and environmentally friendly energy source, we have yet to identify a LCA study that has even identified the quite manifest combustible dust fire and explosion risks, less, of course, has sought to address this adverse effect in the policy recommendations. The Danish Energy Authority recently tendered for an analysis of environmental and climate effects of producing and using biomass for electricity, heat and transportation in Denmark (DEA 2012b). The tender is silent on safety issues. This corroborates the general picture, that environmental sustainability interventions seem to have a blind spot towards occupational accident risk.

\section{Evidence of Limited Information Exchange and Learning}

Most industrial accident prevention professionals are familiar with the Heinrich triangle and its stipulation that every major accident is preceded by a number of minor accidents, which in turn are preceded by a larger number of near-misses (Phimister et al. 2004). According to this theory, we will soon be running out of luck.

After the 2012 Tilbury Power Station, UK, fire the company RWE conducted an internal investigation. There are some suggestions that the pellet fire may have started on a conveyor belt. While this may have a familiar ring, the real concern to accident prevention professionals should be the popular practice of carrying out internal investigations, which are not released into the public domain. This is also true for major Danish players that although being certified to ISO 14001 and OHSAS 18001, and having Corporate Social Responsibility (CSR) policies do not engage in broad lessons learned dissemination activities to prevent recurrence elsewhere.

It is a familiar and age old problem across industries. It's a shame. It is also only to be expected. Milton Friedman's dictum “The business of business is business" implies that spending company resources to investigate and report lessons learned for the benefit of others would make a weak business case. Only expenses are visible; negative publicity is a concern and benefits are at best uncertain and intangible. We believe that some sort of regulatory intervention is required to translate the seemingly straightforward ideal of information sharing into something workable in practice. 
The failure to do so and the general failure to address safety risks appear particularly disheartening in a setting with brimming Danish ambitions to become the world leader in sustainable biomass usage, no expenditure spared, and colossal costs passed to tax-payers and energy consumers.

\section{Media Shifting and Inherent Safety- Two Under-Studied Issues}

While the concept of media shifting is not new (Ashford 1997) we argue that the attention given to the subject has been rather limited and that the extent of the problem is under-studied. We remark that media shifting can be observed in other environmental interventions. We provide two examples.

First, we note that flue gas $\mathrm{NO}_{\mathrm{X}}$ reduction by means of Selective Catalytic Reduction (SCR) technology requires injection of ammonia into the smokestack. While the SCR technology is very clever, two toxic substances react to produce inert nitrogen, the introduction of toxic ammonia creates a new hazard at the workplace. To the extent that the process is designed for anhydrous ammonia, a liquefied toxic gas stored under pressure, road transport of this substance creates new hazards and the anhydrous ammonia storage vessel at the site may constitute a hazard for the surrounding community. For safety reasons, some countries, e.g., USA, only permit the use of an aqueous ammonia solution, which is considerably less hazardous than anhydrous ammonia. Anhydrous ammonia is the least expensive reagent to use from a capital and operating cost basis however, and is popular in Danish SCR units.

Second, we draw attention to the emerging practice of shifting from diesel or other nonvolatile oils to natural gas as a transportation fuel. We argue that this change runs counter to long established core principles of inherent safety and risk reduction, for instance laid down in the ATEX directive, because a low-risk fuel is substituted for a high-risk one. At present, there are two drivers for this change, an economic and an environmental driver. Large discoveries of natural gas in shale-rock formations throughout North America and elsewhere are reshaping fuel markets pushing natural-gas prices down at a time when diesel costs have soared due to higher world petroleum prices (WSJ 2012). The environmental driver is a desire to curb carbon dioxide 
emissions from the transportation sector ${ }^{2}$, which has so far proven to be difficult. As safety professionals we are particularly troubled by the introduction of liquefied natural gas (LNG) in ferryboats and passenger vessels because of the large number of people onboard, the inability to escape in case of explosion and fire, and the tremendous obstacles associated with evacuation of large numbers of passengers from a damaged vessel at sea. Vinnem (2008) criticizes the location of an LNG facility for bunkering of marine vessels in Risavika, Norway, claiming that the contribution to societal risk was insufficiently addressed.

The Danish authorities recently carried out a North European LNG marine infrastructure feasibility study. The study considered benefits in a strategic perspective and stated that LNG is an obvious fuel alternative as it has environmental and climate change (and cost) advantages compared to oil-based fuels (DMA 2012). In stark contrast, safety issues were not given strategic consideration. The study considered loading of LNG tank trucks a "well established technique" and was satisfied that road traffic with LNG trucks is "subject to detailed national and local safety regulations" and hence, by implication, presumably a negligible hazard. Potential thirdparty concerns were waved away as "lack of knowledge and scaremongering" and it was hoped that stringent classification rules and regulations for gas carriers would make them "equally safe as other types of ships and will not pose any additional risk contribution to the ship traffic situation at sea and in ports" (DMA 2012:161-162).

The tendency to prioritize environmental benefits over safety concerns seems to run deep and not confined to the realm of solid biomass only.

\section{CONCLUSION}

This paper argues that solid biomass is not only greener and more expensive than coal, it is also more dangerous, and that the unsafe properties of biomass have been largely overlooked in the haste to cut greenhouse gas emissions.

Biomass pellets generate combustible dust in quantities presenting a serious dust explosion hazard, the blast from the explosion is more severe and because pellets are sensitive to moisture

${ }^{2}$ The substitution will also curb sulphur dioxide emissions from ship engines. We do not consider this as an environmental driver, as it could be achieved simply by using low-sulphur diesel. 
they are handled in enclosures, which increase the dust explosion risks. They easily ignite, from friction or sparks, and may self-ignite if moist. Smoldering fires are difficult to detect and embers may migrate in the conveyor systems and develop into massive storage fires that cause extensive damage.

Wood dust hazards at lumber yards and sawmills may have been grandfathered as tolerable risks. The number of facilities is limited however, and the quantities handled relatively modest. This changes dramatically if solid biomass is used for power and heat generation. The intensification and complexities that come with the rapid scale-up and the handling of unprecedented quantities of solid biomass fuels call for increased attention to safety. The number of serious accidents indicates that biomass pellets represent an emerging risk for which proper control strategies have yet to be developed.

Environmental ambitions are very high and the costs to society of introducing solid biomass fuels are breathtaking. In this setting, the general failure to address safety risks appears particularly disheartening. Further research is needed to provide policy guidance on how to improve this situation. Because there is currently no mechanism to register fire and explosion incidents involving biomass pellets, a natural starting point would be to rectify this shortage of fundamental data. Systematic incident information capture and exchange, understanding the fundamental root causes, widely disseminating the lessons learned, and integrating these lessons learned into safe operations, are key to improving the safety performance of the expanding bioenergy industries.

\section{ACKNOWLEDGEMENTS}

This article has been produced as voluntary work and has not received any funding. Opinions expressed are those of the authors, not their employers' or organizations'.

\section{CORRECTION}

An earlier version of the accepted author version posted online (in-press posting) misstated the flue gas NOx reduction technology in use at Danish power plants. It is Selective Catalytic Reduction (SCR), not Selective Non-Catalytic Reduction (SNCR) 


\section{REFERENCES}

Andersen U. 2012. Entreprenør frikendt: Amagerværket skulle have advaret mod eksplosionsfare [Contractor acquitted: power plant should have warned about explosion hazard]. Ingeniøren 27. Nov 2012. Available at http://ing.dk/artikel/entreprenor-frikendt-amagervaerket-skulle-have-advaret-mod-eksplosionsfare-134432, (retrieved 30 Sep 2013, in Danish), Copenhagen, Denmark

Ashford NA. 1997. Industrial safety: the neglected issue in industrial ecology. J Clean Prod 5(1-2):115-21

Ashford NA. 2012. Reducing physical hazards: encouraging inherently safer production. In: Boethling R, Voutchkova A, and Anastas P (eds), Designing Safer Chemicals Handbook of Green Chemistry Series 9:485500. Wiley-VCH, Weinheim, Germany:

BI (Business Insider). 2012a. Germany is spending 8\% of its GDP on a huge, risky shift to renewable energy. Business Insider, Mar 20, 2012. Available at http://www.businessinsider.com/germany-is-spending-8-of-itsgdp-on-a-huge-risky-shift-to-renewable-energy-2012-3, (retrieved 28 Sep 2013). New York, USA

BI. 2012b. Denmark has agreed on an incredibly ambitious green energy plan. Business Insider. Mar 27, 2012. Available at www.businessinsider.com/denmark-wind-energy-2012-3, (retrieved 30 Mar 2013). New York, USA

Bredsdorff M. 2012. Ny silo-brand i træpiller: Amagerværket delvist evakueret [New pellet fire in silo: Power plant partly evacuated]. Ingeniøren 17. Dec 2012. Available at http://ing.dk/artikel/ny-silo-brand-i-traepilleramagervaerket-delvist-evakueret-135034, (retrieved 30 Sep 2013, in Danish). Copenhagen, Denmark

Butcher J. 2011. Firefighters battle huge biomass fire at Port of Tyne. The Journal, 31 Oct 2011. Available at http://www.thejournal.co.uk/news/north-east-news/firefighters-battle-huge-biomass-fire-4422494, (retrieved 29 Sep 2013). Newcastle upon Tyne, England

BZ (Badische Zeitung). 2009. Wieder Staubexplosion bei German Pellets [Another dust explosion at German Pellets]“. Badische Zeitung, 5 Jan 2009. Available at http://www.badische-zeitung.de/wieder-staubexplosionbei-german-pellets, (retrieved 4 Sep 2012, in German). Freiburg im Breisgau, Germany

CSB (US Chemical Safety Board). 2009. Investigation Report. Sugar Dust Explosion and Fire (14 Killed, 36 Injured). Imperial Sugar Company. Port Wentworth, Georgia, Feb 7, 2008. Report No. 2008-05-I-GA. Washington DC, USA

DEA (Danish Energy Authority). 2012a. Martin Lidegaard: Vi skriver energipolitisk historie [We make history in energy policy]”. Available at http://www.ens.dk/info/nyheder/nyhedsarkiv/martin-lidegaard-skriverenergipolitisk-historie, (retrieved 28 Sep 2013, in Danish), Copenhagen, Denmark

DEA. 2012b. Invitation For Tender. Analysis of Environmental and Climate Effects of Producing and Using Biomass for Electricity, Heata and Transportation in Denmark. 17 Dec 2012. Copenhagen, Denmark

DMA (Danish Maritime Authority). 2012. North European LNG Infrastructure Project. A feasibility study for an LNG filling station infrastructure and test of recommendations. Søfartsstyrelsen, 30 May 2012. Copenhagen, Denmark

DMCEB (Danish Ministry of Climate, Energy and Building). 2012. Energy Policy Report 2012. Report from the 
Ministry of Climate, Energy and Building to the Danish Parliament”, 9 May 2012. Available at

http://www.ens.dk/sites/ens.dk/files/politik/dansk-klima-energipolitik/regeringens-klima-energipolitik/energiklimapolitiske/Energy\%20Policy\%20Report\%202012.pdf, (retrieved 28 Sep 2013), Copenhagen, Denmark

Dujardin RC. 2013. Explosion ignites factory blaze in East Providence. The Providence Journal, Aug 20, 2013.

Available at http://www.providencejournal.com/breaking-news/content/20130820-explosion-ignites-factoryblaze-in-east-providence.ece?ssimg=1153615, (retrieved 23 Aug 2013). Providence, Rhode Island, USA

Econ. 2013. Carbon trading, ETS, RIP? Economist, Apr 20, 2013

FAS (USDA Foreign Agricultural Service). 2013. EU biofuels Annual 2013. Global Agricultural Information Network (GAIN). GAIN Report Number: NL3034. Washington, DC, USA

ForestTalk. 2010. Explosion at Pacific BioEnergy’s pellet plant in Prince George, British Columbia. ForestTalk, Dec 19, 2010. British Columbia, Canada

Gauthier S, Grass H, Lory M, et al. 2012. Lethal carbon monoxide poisoning in wood pellet storerooms - two cases and a review of the literature. Ann Occup Hyg 54(7):833-41

Guardian. 2012. Firefighters battle Essex power station blaze. The Guardian, 27 Feb 2012. Available at http://www.theguardian.com/uk/2012/feb/27/firefighters-essex-power-station-blaze, (retrieved 29 Sep 2013)

Hedlund FH. 2002. Incorporation of Occupational Health and Safety in Cleaner Production Projects in South Africa. Ph.D Thesis. Aalborg University, Aalborg, Denmark

Hedlund FH, Astad J, and Nichols J. 2014. Inherent hazards, poor reporting and limited learning in the solid biomass energy sector: a case study of a wheel loader igniting wood dust, leading to fatal explosion at wood pellet manufacturer. Biomass Bioenergy 66:450-9

Huéscar Medina C, Phylaktou HN, Sattar H, et al. 2013. The development of an experimental method for the determination of the minimum explosible concentration of biomass powders. Biomass Bioenergy 53:95-104

Johannsen K. 2011. Træpiller vs. kul på de centrale kraftværker - en samfundsøkonomisk analyse af omstillingen i de større danske byer. [Wood pellets versus coal at major power plants - a socio economic analysis]. Aarhus University, School of Business, June 2011. (MSc thesis, in Danish). Aarhus, Denmark

Kalunian K. 2013. Fire Department visited Inferno 42 times in last year. WPRO News. Available at http://www.630wpro.com/common/page.php?pt=NEWS\%3A+Fire+Department+visited+Inferno+42+times $+\mathrm{i}$ $\mathrm{n}+$ last+year\&id=20453\&is_corp=0, (retrieved 23 Aug 2013).

Melin S. 2008. Testing of explosibility and flammability of airborne dust from wood pellets. Wood Pellet Association of Canada, Nov 2, 2008. Revelstoke, British Columbia, Canada

Murray G. 2010. Prevent fires, explosions. Canadian Biomass Magazine. Sep-Oct 2010. Available at http://www.canadianbiomassmagazine.ca/index.php?option=com_content\&task=view\&id=2023\&Itemid=132 , (retrieved 30 Sep 2013). Simcoe, Ontario, Canada

NZH (The New Zealand Herald). 2013. Large explosion at factory near Taupo, Sep 4, 2013. Available at http://www.nzherald.co.nz/nz/news/article.cfm?c_id=1\&objectid=11119046, (retrieved Sep 4, 2013)

OJ. 2009. Directive 2009/28/EC of the European Parliament and of the Council of 23 April 2009 on the promotion of the use of energy from renewable sources and amending and subsequently repealing Directives 
2001/77/EC and 2003/30/EC (Renewable energy Directive). Official Journal of the European Union, L $140 / 16(5.6 .2009)$

Osborne S. 2012. Port Panama City fire contained. wjhg.com, May 03, 2012. Available at www.wjhg.com/news/headlines/Port_Panama_City_Fire_Contained.html?ref=735 (retrieved 28 Apr 2013).

OSHA (US Occupational Safety and Health Administration) . 2012. Citation and Notification of Penalty. New England Wood Pellets, LLC. Inspection number 108074, dated 4/17/2012. Washington, DC, USA

PE (Process Engineering (UK)). 2012. RWE studying Tilbury Power Station fire. Process Engineering (UK), 13 July 2012. Available at http://processengineering.theengineer.co.uk/rwe-studying-tilbury-power-stationfire/1013136.article, (retrieved 30 Sep 2013).

Phimister JR, Bier VM, and Kunreuther HC (eds). 2004. Accident precursor analysis and management: reducing technological risk through due diligence. National Academies Press. Washington, DC, USA

RIM (Renewables International Magazine). 2011. Following explosion, world's largest pellet plant resumes operation. $15 \mathrm{Jul}$ 2011. Available at http://www.renewablesinternational.net/following-explosion-worldslargest-pellet-plant-resumes-operation/150/515/31440/, (retrieved 28 Sep 2013) (English version of ErneuerbareEnergien.de, Hannover, Germany)

Rupp W. 2013. Update: Firefighters at pellet company blaze searching for 'hidden fires'. East Providence Patch. Available at http://eastprovidence.patch.com/groups/police-and-fire/p/update-firefighters-at-pellet-companyblaze-searching-for-hidden-fires?goback=\%2Egde_1184577_member_267625347, (retrieved 22 Aug 2013).

SMN (Savannah Morning News). 2012. Fire breaks out at Savannah's East Coast Terminal Company. May 16, 2012. Available at http://savannahnow.com/latest-news/2012-05-16/fire-breaks-out-savannahs-east-coast-terminalco, (retrieved 28 Apr 2013). Savannah, Georgia, USA

Vaughan D. 1996. The Challenger launch decision. Risky technology, culture, and deviance at NASA. University of Chicago Press. Chicago, USA.

Vinnem JE. 2008. Gransking av svikt av samfunnsmessige barrierer [Review of failure of (regulatory) barriers]. Preventor, Rapport 200800-01. Oct 2008, Bryne, Norway, (in Norwegian).

VS (The Vancouver Sun) 2012. Two dead, 22 injured after massive explosion destroys Prince George sawmill. Second deadly B.C. sawmill explosion this year, Apr 25, 2012. Vancouver, Canada

Weinreich E. 2012. Absolut en ekstraordinær hændelse [Absolutely an extraordinary event]. Brandvaesen, Sep 2012, pp10-19, Sorø, Denmark (in Danish).

WorkSafeBC. 2013. Incident Investigation Report. Explosion at Babine Forest Products, Jan 20, 2012. WorkSafe British Columbia, Canada, investigation file number 2012-0013. Date: Nov 29, 2012; amended Aug 29, 2013. Canada

WorkSafeBC. 2014. Incident Investigation Report. Explosion at Lakeland Mills, Apr 23, 2012. WorkSafe British Columbia, Canada, investigation file number 2012-0044. Date: Nov 29, 2012; amended Jan 27, 2014. Canada WSJ (Wall Street Journal).. 2012. Ferry systems look to switch to natural gas. As rising diesel costs squeeze budgets, operators consider converting vessels to run on LNG amid boom in shale gas. Jun 24, 2012. New York, USA 
Zwetsloot GIJM and Ashford NA. 2003. The feasibility of encouraging inherently safer production in industrial firms. Safety Sci 41(2-3):219-40 